\title{
Relationship Between Inspiration Characters and the Resilience of Prospective Educators in Facing the Disruption
}

\author{
Awalya Awalya ${ }^{1}$, Imam Setyo Nugroho ${ }^{2}$, Weni Anggraini ${ }^{3}$, Susilawati Susilawati ${ }^{4}$ \\ \{awalya@mail.unnes.ac.id ${ }^{1}$, imamsetyo84@students.unnes.ac.id ${ }^{2}$,weniang26@gmail.com ${ }^{3}$ \\ susilawati0106517056@students.unnes.ac.id $\left.{ }^{4}\right\}$ \\ Universitas Negeri Semarang, Semarang Indonesia ${ }^{1,2,3,4}$
}

\begin{abstract}
The disruption era is a period of disruption and uncertainty marked by technological advances in various fields creating opportunities and challenges. Inspiring characters and high levels of resilience are important for prospective educators to have. The aim of the study was to determine the relationship between inspiring characters and the level of resilience of prospective educators. The research method uses a correlational method, with a study sample of 64 UNNES Guidance and Guidance Masters students. The results showed that there was no significant relationship between inspiring characters and the level of resilience of prospective educators $(r=0.116, p<0.05)$, this means that prospective educators who have high inspirational characters do not necessarily have high resilience and vice versa. This finding is expected to be the basis for the development of educational programs for prospective educators to have an inspiring character and resilience in facing challenges. The era of disruption.
\end{abstract}

Key words: inspiration characters, resilience, disruption era

\section{Introduction}

The development of human life from traditional times to modern times has an influence on the development of human needs and ways of life. In the beginning, human life was very simple, which only used makeshift equipment available in nature. As time went on, humans increasingly developed. From the use of steam engines to help alleviate human work then the use of electricity and until now human life has evolved into automation in various fields of life. This era of automation is known as the development of industry 4.0 and is also known as the era of disruption. The industrial revolution 4.0 is the birth of digital technology that encourages automation systems in all processes of activity and has a massive impact on human life throughout the world ${ }^{[1]}$.

In the modern era, developing human life also requires humans to be able to survive and be able to meet the demands of an increasingly sophisticated era. The 4.0 industrial revolution in the next five years will remove 35 percent of the work [2], even in the next 10 years the type of work that will be lost will increase to 75 percent. This is because the work played by humans step by step is replaced by the program digitalization technology. Thus, careful preparation is needed for individuals to be able to compete in their lives. Preparation of human beings who are usually through educational channels both formally and informally. To prepare students who are qualified and able to deal with the development of the times treated by various factors that 
must be prepared, namely: a) competent educator resources; b) supporting facilities and infrastructure; and c) educational environment.

Educator resources as the main spearhead that will shape students who are able to face the demands of the times, are expected to have greater resilience and have inspiring characters. Resilience in facing challenges is an understanding of resilience. Resilience is the ability of a person to judge, overcome, and improve themselves and change themselves from adversity or misery in life[3]. Furthermore resilience is the capacity to respond in a healthy and productive manner when facing difficulties or trauma, which is important in managing the stresses of everyday life[4].

The level of resilience that a person has also has a close relationship with the character of that person. Character is a complex psychological construct, predisposing behavior to someone to act as a moral agent[5]. Besides that, character is the values of human behavior that are related to God Almighty, oneself, fellow human beings, environment, and nationality which are manifested in thoughts, attitudes, feelings, words, and actions based on religious norms, law, etiquette, culture, and customs[6]. While inspiration is a message that is obtained from an activity or event or situation that touches emotions and contains disclosure and awareness, so as to make people who get it moved to follow up into concrete actions[7]. Thus it can be said that the character is inspirational is a strong tendency in a person to give a touch of emotion and awareness of individuals in understanding and living the moral values of life that are reflected in the actions, attitudes and interactions of individuals with their environment.

Resilience competencies in the face of the times and inspiring characters must be prepared for prospective educators. Therefore, it is necessary to know the level of resilience and inspirational character, and the relationship between the two for prospective educators. The results of the study on the relationship between character strength and resilience in students, showed that student resilience is positively related to several dimensions of character strength, namely the most powerful relationship with resilience is persistence, then social intelligence, citizenship, spirituality, leadership, bravery, and open-mindedness[8]. Furthermore, research on the relationship between character strength and the resilience of drug resident in the therapy technical implementation unit and rehabilitation of the National Narcotics Agency Lido. The results showed that there was a significant positive relationship between character strength and resilience. The level of relationship between character strength and resilience is $62.7 \%[9]$.

Based on the results of research that has been conducted which states that there is a relationship between resilience and character strength. So in this study we will examine the relationship between resilience and inspirational character for prospective educators who will focus on meeting needs and demands in the era of disruption. Thus to answer the challenges in this modern era, it is necessary to know the level of resilience and inspirational character of students and the relationship between the two. The purpose of this study was to determine the level of resilience and inspirational character of students and the relationship between the two. The benefit of this research is to know the level of resilience and inspirational character of students and the relationship between the two. In addition, this research is also the basis for the creation of character-based educational programs for prospective educators and based on the level of resilience of prospective educators. 


\section{Methods}

This study included an ex post facto study using a quantitative approach with a correlation design. The research variables are inspirational character and resilience. The subjects of this study were 64 students after the 2017 guidance and counseling service class who were selected purposively. The process of data collection is done by distributing the scale developed by researchers, namely the scale of resilience consisting of 36 items of questions from emotion regulation indicators, implus control, optimism, cause analysis, empathy, achievement selfefficacy. The assessment of the instrument is in the form of a Likert scale, where there are questions that are of favorable value and some are worth unfavorable with five choices of answers ranging from very appropriate to very inappropriate. The validity of the instrument ranged from 0.306 to 0.641 and the reliability was 0.812 . While the inspirational character scale consists of 29 items of questions from constructs of moral actions, moral values, moral emotions, moral reasoning and moral identity. The assessment of the instrument is in the form of a Likert scale, where there are questions that are of favorable value and some are worth unfavorable with five choices of answers ranging from very appropriate to very inappropriate. The validity of the instrument ranged from 0.519 to 0.752 and the reliability was 0.905 . Next to find out the results of the study, the data were analyzed using Pearson Product-moment difference test analysis using SPSS 23.

\section{Results and Discussion}

The description of the results of the overall research can be seen in table 1 which informs about the description of inspirational characters and the level of resilience in Postgraduate Guidance and Counseling students at Semarang State University. Based on table 1, it can be seen that the description of the level of inspirational character of postgraduate students of Guidance and Counseling in Universitas Negeri Semarang is $43.8 \%$ in the high category and $56.2 \%$ is in the medium category. While the level of resilience is $70.3 \%$ high and $29.7 \%$ is moderate. So that overall it can be known that the inspirational and reselient levels are in the high category.

Table 1 Percentage Description Of Inspirational Character Level And Resilience Level

\begin{tabular}{lccccl}
\hline \multicolumn{1}{c}{ Interval } & \multicolumn{2}{c}{$\begin{array}{c}\text { Inspirational } \\
\text { Characters }\end{array}$} & \multicolumn{2}{c}{ Resilience } & Criteria \\
\hline & F & Percentage & F & Percentage & \\
$64 \%-100 \%$ & 28 & $43.8 \%$ & 45 & $70,3 \%$ & High \\
$34 \%-63 \%$ & 36 & $56.2 \%$ & 19 & $29.7 \%$ & Is Being \\
$1 \%-33 \%$ & - & - & - & - & Low \\
Total & 64 & & 64 & & \\
\hline
\end{tabular}

The data analysis technique used in this study is the Pearson Product-Moment test. Before analyzing the data using hypothesis testing with Pearson Product Moments, especially must have to do a series of assumption tests which include normality test and linearity test. Tests for assumptions and hypothesis testing were carried out with the help of SPSS version 23. Testing for data normality was done using Kolmogorov Smirov, based on the results of the test variables 
in this study were normal ( $p=0.200>0.05$ ) while the results of linearity tests in this study showed that the value the score of each variable is linear $(p=0.237>0.05)$.

Table 2 Pearson Product-Moment Test Results

\begin{tabular}{|c|c|c|c|c|}
\hline \multirow[b]{2}{*}{ Variabel } & \multirow[b]{2}{*}{$\mathbf{N}$} & \multicolumn{2}{|c|}{ Pearson Corelation } & \multirow[b]{2}{*}{ Criteria } \\
\hline & & $\begin{array}{l}\text { Inspirational } \\
\text { Characters }\end{array}$ & Resilience & \\
\hline $\begin{array}{c}\text { Inspirational } \\
\text { Characters }\end{array}$ & 64 & 1 & $0.116 "$ & \multirow{2}{*}{$\begin{array}{c}\text { Sig. } \\
\mathrm{p}<0,05\end{array}$} \\
\hline Resilience & 64 & $0.116 "$ & 1 & \\
\hline
\end{tabular}

Hypothesis testing is done using the Pearson Product-Moment test. The results of the hypothesis test in table 2 show that the level of resilience and the level of inspirational characters are negatively related. Correlation between the level of resilience and the level of inspirational character $(r=0.116, p<0.05)$. Evidently there is no correlation between the level of inspirational character and the level of resilience.

This research is intended to see the relationship between inspirational character and the level of resilience. In general, the Postgraduate Guidance and Counseling students of Universitas Negeri Semarang have an inspirational level and a high level of resilience. The results of hypothesis testing between inspirational characters and the level of resilience show a negative or no correlation between the two. The results of this study are different from the results of previous studies showing that the character's strength does not focus on inspiring characters but rather refers to the overall character. Where in the study the dimensions of the character under study included persistence, social intelligence, citizenship, spirituality, leadership, bravery and open mindedness[8] .

In line with that other studies also show that character education has a positive relationship with resilience [10]. This shows that character formation through education must be accompanied by high levels of resilience that students have. Because good character will be formed with full challenges and sacrifices and not something easy, so that resilience can be the basis for forming good character. Besides that a student who is also a teenager seen from his development stage should have a high level of resilience indicated by adolescents having positive values and good judgment on life today, better physical changes, having hope and being responsible for their own lives, independent, optimistic, have the ability to solve problems, have impulse control and self-efficacy, can take lessons from life, be realistic about the good things that can be done, and have gratitude [11].

The interesting thing in this study and different from previous studies is that there is no relationship between inspiring characters and the level of resilience that students have. Seen from each indicator, it also found the same thing, namely there was no correlation or relationship between the indicators of each inspirational character, namely moral action, moral value, moral emotion, moral reasoning, moral identity with the level of resilience possessed by students. While the results of research related to adolescent moral emotion show that moral emotions have a relationship with the level of resilience possessed by adolescents[12] Where the low resilience of adolescents can be seen from the feelings that often arise that is easy to be afraid, sad, confused, concerned, feeling guilty, anxious, disappointed, and easily worried. Moral emotional connection with resilience can be seen from the understanding of moral emotion itself, where moral emotion is an emotion that responds to moral violations and motivates a 
person to perform certain behaviors and has the power to motivate good deeds and avoid doing bad things [13]. There are two components to identifying moral emotion, namely moving someone who is not interested (disinterested elicitor) and the ability to move the tendency of individual behavior towards goodness (prosocial action tendencies)[14] . So that theoretically there is a relationship between moral emotion and resilience, but the results of this study show the opposite.

This research complements previous research related to character and resilience, besides this research also begins for further research related to the character of integrity and resilience in students. Where both have a very important role in the framework of developing potential and facing the future in the era of disruption. this research can also be grounded to develop learning programs in higher education especially in the field of guidance and counseling to focus more on developing inspirational characters and increasing student resilience to be easier in going through the process of education in higher education.

\section{Conclusion}

The results showed that the postgraduate guidance and counseling students of Universitas Negeri Semarang had a high level of inspiration and resilience. However, in this study there was no relationship between high inspirational rates and high levels of resilience. So it can be concluded that students who have high inspiration do not necessarily have a high level of resilience or vice versa. Based on the results of the study, it is expected that further research will include cultural variables in the study, so that they can be identified further regarding the inspirational level and its resilience.

Acknowledgments. The author would like to thank the postgraduate of Universitas Negeri Semarang for funding research and facilitating the writing of this article 


\section{References}

[1] Schwab, K. The fourth industrial revolution. Crown Business Press. (2017).

[2] Karnawati, D. Revolusi industri, $75 \%$ jenis pekerjaan akan hilang. Diambil dari https://ekbis.sindonews.com/read/1183599/34/revolusi-industri-75jenis-pekerjaan-akan-hilang-488169341. (2017).

[3] Grothberg, E. A guide to promoting resilience in children: strengthening the human spirit. the series early childhood development: practice and reflections. no 8 . The Hangue: Benard Van Leer Voundation. (1995).

[4] Reivich, K \& Shatte, A. The resilience factor. New York: Broadway Book. (2002).

[5] Berkowitz, M. W. \& Bier, M. C. Research based character education. The Annals Of The American Academy, 591, 72-85.(2004).

[6] Muslich, M. Pendidikan karakter: menjawab tantangan krisis multidimensional. Jakarta: Bumi Aksara. (2011).

[7] Lawoto Cakrajono. Buku sakti pagi pengejar inspirasi. Jakarta: PT. GRamedia Pustama Utama. (2014).

[8] Listiyandini, R.A., \& Akmal, S.Z. hubungan antara kekuatan karakter dan resiliensi pada mahasiswa. Prosiding temu ilmiah nasional psikologi. Jakarta: Fakultas Psikologi Universitas Pancasila. (2017).

[9] Handayani, F. Hubungan antara kekuatan karakter dan resiliensi residen narkoba di unit pelaksana teknis terapi dan rehabilitasi badan narkotika nasional lido. Skripsi Universitas Islam Negeri Syarif Hidayatullah. (2010).

[10] Uyun, Z. Resiliensi dalam pendidikan karakter. Seminar Nasional Psikologi Islami..(2012).

[11] Ambarwati \& Pihasniwati. Dinamika resiliensi remaja yang pernah mengalami kekerasan orang tua. PSIKOLOGIKA: Jurnal Pemikiran dan Penelitian Psikologi. (2017).

[12] Pratiwi, M. S., \& Adiyanti, M. G. Studi pendahuluan: emosi moral pada remaja. Jurnal Psikologi Perseptual, 2(2), 69-87. (2017).

[13] Tangney,J.P., Stuewig, J. \& Mashek, D.J. Moral emotions and moral behavior. Annual. Rev. Psychology, 58, 345-72.(2006).

[14] Haidt,J. The moral emotions handbook of affective sciences (pp. 852-870). Oxford: Oxford University Press. (2003). 